\title{
Municipal Instruments in Law for Cultural Heritage Protection: A Case Study of the City of Cape Town Metropolitan Municipality
}

\section{P.E.R}

Pioneer in peer-reviewed, open access online law publications

Author

Melandri Steenkamp

Affiliation

North-West University

South Africa

Email

melandristeenkamp@gmail.com

Date Submission

12 June 2019

Date Revised

8 March 2021

Date Accepted

16 July 2021

Date published

1 September 2021

Series Editor Prof AA du Plessis

Section Editor Prof AA du Plessis

How to cite this article

Steenkamp RM "Municipal

Instruments in Law for Cultural

Heritage Protection: A Case Study

of the City of Cape Town

Metropolitan Municipality"PER /

PELJ 2021(24) - DOI

http://dx.doi.org/10.17159/1727-

3781/2021/v24i0a6435

Copyright

DOI

http://dx.doi.org/10.17159/1727-

3781/2021/v24i0a6435

\begin{abstract}
The premise of this article is that local government can add to the protection effort of cultural heritage resources in South Africa by way of instruments such as by-laws, planning instruments and local policies. Cultural heritage resources in the context of this article include both tangible and intangible manifestations of culture and heritage. Schedule $4 \mathrm{~A}$ of the Constitution of the Republic of South Africa, 1996 (the Constitution) assigns "cultural matters" to national and provincial governments as a concurrent function. Municipalities are expected to execute aspects of this function based on a few rights in the Constitution (sections 15, 30, 31 and 24) as well as the heritage, environmental and local government framework legislation and policy documents of South Africa. As a first step to assess what local government can de jure contribute to cultural heritage protection and management, this article evaluates the national legislative framework for cultural heritage resource management (CHRM) and explores the instruments it creates for municipalities to help give effect to CHRM. To give life to this analysis, the article further probes into a select few instruments of the City of Cape Town Metropolitan Municipality and two specific court cases concerning CHRM in the City.
\end{abstract}

\section{Keywords}

Cultural heritage resources; local government; by-laws; integrated development plans; spatial development frameworks; planning law; City of Cape Town; South Africa. 


\section{Introduction}

Cultural heritage serves an important function in society, including in cities that are home to millions of people and various cultures globally. ${ }^{1}$ In combination with the unabated urbanisation occurring in many parts of the world, it is understandable that international urban development policies increasingly call for the safeguarding, promotion and sustainable management of natural and cultural heritage, both tangible and intangible. ${ }^{2}$ Although the terms "culture", "heritage" and "cultural heritage resources" are often used interchangeably, they are typically defined differently. ${ }^{3}$ Some descriptions consider cultural heritage as being a reflection of cultural value, a term that conjures up notions such as significance, reflected both through tangible and intangible manifestations, ${ }^{4}$ whereas others suggest that "cultural resources" refers to materials that have been chosen by societies as being relevant to their existence, and which might serve several purposes, including the political, economic and psychological. ${ }^{5}$ In the context of this article, "cultural heritage resources" refers to both tangible and intangible manifestations of culture and heritage and includes the cultural properties associated with the broader built and natural environment. ${ }^{6}$

In South Africa a high premium is placed on the protection of cultural heritage for reasons ranging from nation-building to socio-economic development. ${ }^{7}$ The Constitution of the Republic of South Africa, 1996 (the Constitution) acknowledges the importance of the protection of cultural heritage in the form of entrenched rights to culture, language and religion (sections 15, 30 and 31). Adding to these provisions is the main authority

Melandri Steenkamp. LLB LLM (NWU). Doctoral candidate, South African Research Chair in Cities, Law and Environmental Sustainability (CLES), Faculty of Law, NorthWest University, South Africa. Email: melandristeenkamp@gmail.com. ORCID: https://orcid.org/ 0000-0003-3380-9087. This research was conducted with the financial support of the National Research Foundation of South Africa (NRF) (Grant No: 115581). All views and errors are the author's own and do not represent the views of the NRF. I wish to thank Prof Oliver Fuo and Dr Brews Soyapi as well as the anonymous reviewers for their valuable inputs into earlier drafts of this article.

1 Pereira Roders and Van Oers 2012 Journal of Cultural Heritage Management and Sustainable Development 5.

UN-Habitat World Cities Report 2020 172. Also see Owosuyi 2015 PELJ.

3 See inter alia these works on the definitions of cultural heritage: Roodt 2006 Fundamina; Deacon et al Subtle Power of Intangible Heritage; National Heritage Council Critical Reflections on Heritage.

Forrest International Law and the Protection of Cultural Heritage 2.

Keitumetse African Cultural Heritage Conservation and Management 5.

Deacon, Mngqolo and Prosalendis Protecting our Cultural Capital 1. See section 2 for a discussion of the definitions.

DAC Revised White Paper on Arts, Culture and Heritage Fourth Draft 8. 
for the management of cultural heritage resources $(\mathrm{CHRM})^{8}$ in South Africa, the National Heritage Resources Act 25 of 1999 (NHRA), which assigns the responsibility for and mandate to manage heritage resources to the national, provincial and local spheres of government. ${ }^{9}$ Moreover, the provisions of the Constitution and the NHRA, read together with environmental legislation such as the National Environmental Management Act (NEMA), ${ }^{10}$ strongly suggest that there is a definite role for local government in the protection and management of heritage resources. ${ }^{11}$ The role of local government entails inter alia identifying Grade III heritage resources, developing an inventory of heritage resources, and drafting municipal by-laws for the management of such resources. ${ }^{12}$

The premise of this article is that local government can help protect cultural heritage resources in South Africa by way of instruments such as by-laws, planning instruments and local policies. The Constitution allocates the function of cultural matters to national and provincial governments as a concurrent function under Schedule 4A. Municipalities are expected to execute aspects of this function as per the Constitution as well as the heritage, environmental and local government framework legislation and policy documents. As a first step towards assessing what local government can de jure contribute to the protection of cultural heritage, this article evaluates the national legislative framework for the CHRM and explores the instruments it creates for municipalities to help give effect to it.

To give life to this legislative analysis, the article further probes into a select few instruments of the City of Cape Town Metropolitan Municipality and two specific court cases concerning CHRM in the City. It is the only municipality in the Western Cape that has been assessed as and declared as being fully competent in terms of local CHRM by its PHRA, Heritage Western Cape

8 According to the National Heritage Resources Act 25 of 1999 (NHRA), heritage management refers to the identification, protection, conservation, research, recording, documentation, dissemination, revitalisation, and promotion of heritage resources based on the best practices and world standards of management. For convenience's sake, the article uses the terms cultural heritage and cultural heritage resources interchangeably.

9 Section 8 of the NHRA; Kotzé and Jansen van Rensburg 2003 Queensland U Tech L \& Just J 16. Also see Scheermeyer 2005 South African Archaeological Bulletin 121-123; Ndlovu 2011 Conservation and Management of Archaeological Sites 3157.

10 National Environmental Management Act 107 of 1998 (NEMA). S 1 of the NEMA recognises aesthetic and cultural properties as constituents of the environment, with both characteristics being identified in the description of cultural heritage.

11 The terms local government, local authorities and municipalities will be used interchangeably in this discussion.

12 Sections 8(4) and 54 of the NHRA. Also see the discussion in section 3. 
(HWC). The South African Heritage Resources Agency (SAHRA) must declare the competencies of Provincial Heritage Resources Authorities (PHRAs). In return the PHRA may identify a municipality as being competent to perform certain functions under the NHRA and it may delegate further responsibilities, if the municipality is willing to accept them. ${ }^{13}$

The pronouncement of the courts in cases such as Oudekraal Estates (Pty) Ltd $v$ City of Cape Town ${ }^{14}$ and Bo-Kaap Civic and Ratepayers Association $v$ City of Cape Town $n^{15}$ further serves to judicially underscore the important role that local authorities can and should play in matters concerning the management of cultural heritage.

Section 2 provides an outline of the landscape of cultural heritage resources in South Africa with specific reference to local government. The relevance of protecting these resources locally is also reflected upon. Section 3 addresses the legislative basis for CHRM as it applies to local government. Section 4 is the heart of this paper, looking into the instruments in law that enable local government to contribute to CHRM at the local level. Section 5 is an extension of section 4 in the sense that it considers the case of Cape Town, to determine if and how the City has managed to operationalise the law. Thereafter section 6 provides an assessment of two cases in the courts concerning CHRM in the City of Cape Town. The article concludes with views on the suitability of the existing local government instruments as provided for in law and makes recommendations for possible future law reform.

\section{The cultural heritage landscape of South Africa}

South Africa has a rich cultural heritage that is commonly unprotected, unknown, and undiscovered. ${ }^{16}$ The legacy of apartheid was to ensure that the practice and promotion of languages, the performing arts, rituals, social practices, and indigenous knowledge of various social groups remained unbalanced, and in some cases, was actively discouraged. ${ }^{17}$ Following the political transition of 1994 and the coming into being of the interim and final constitutions, legislative reform endorsed the phasing out of past

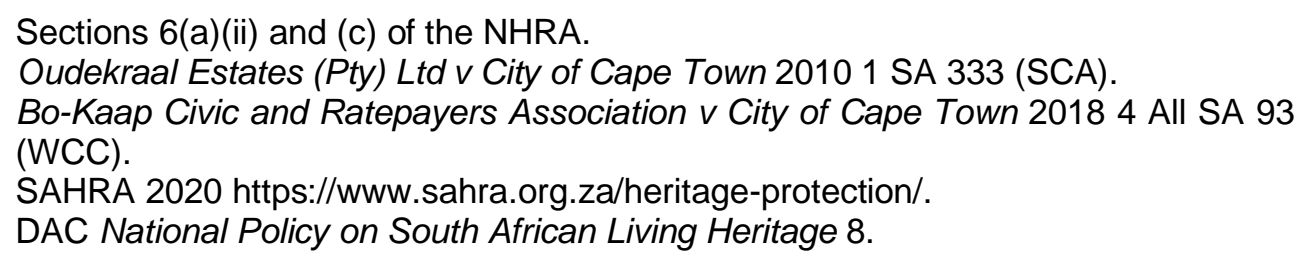


exclusionary heritage laws. ${ }^{18}$ In response, the country sought to redefine and re-imagine its cultural heritage, which included a radical shift in focus to incorporate non-White cultural heritage that had been significantly disregarded during apartheid. ${ }^{19}$ The new dispensation inherited a cultural heritage portfolio that consists of a wide spectrum of museums, archaeological sites, diverse music and art items and products, and rituals, many of which have arguably not been used to the maximum benefit of society at large.$^{20}$ Henceforth the new, democratic state is tasked with the duty of defining and delineating which facets of cultural heritage will receive protection and consideration in a manner that is inclusive and representative of the diversity present in South Africa. ${ }^{21}$

Cultural governance is expected to concern both the tangible and intangible (living) heritage of the country. ${ }^{22}$ It is understood as "government's direct or indirect involvement in the promotion and administration of programmes of cultural organisations (including museums) existing in specific geographic boundaries with unique financial and administrative arrangements (that is, earmarking a certain percentage of sales or property tax to support cultural institutions and activities)". ${ }^{23}$ Furthermore, CHRM takes on the meaning of the identification, interpretation, maintenance, and preservation of significant cultural sites and physical heritage assets, including intangible aspects of heritage, such as traditional skills, cultures, languages and the management of cultural heritage resources.

Tangible heritage refers to a wide range of buildings, structures, townscapes, places or objects of aesthetic value, graves and burial grounds, places of memory, historical settlements, and many more. ${ }^{24}$ It therefore refers to material heritage, which is either movable or immovable and can be natural or man-made. South Africa has a rich tangible heritage inherited from its past generations, which is evident in its many museums,

18 Kotzé and Jansen van Rensburg 2003 Queensland U Tech L \& Just J 12; Deacon, Mngqolo and Prosalendis Protecting our Cultural Capital 9-10.

19 Bredekamp 2006 International Journal of Intangible Heritage 76-77; Butler and Ivanovic "Cultural Heritage Tourism Development" 62.

20 Phaswana-Mafuya and Haydam 2005 Museum Management and Curatorship 150; Butler and Ivanovic "Cultural Heritage Tourism Development" 62.

$21 \quad$ Butler and Ivanovic "Cultural Heritage Tourism Development" 63.

22 See Vollgraaff 2017 South African Museums Association Bulletin 56, who claims that the concept of "cultural landscape" differs from the concepts of "environment" or "heritage resources", because it is more than a collection of tangible heritage resources. Jae Moon 2001 Administration and Society 432-433; Du Plessis and Rautenbach 2010 PELJ 46.

$24 \quad$ Barillet, Joffroy and Longuet Cultural Heritage and Local Government 6. 
memorials and monuments, which highlight the nation's oppressive, divisive and struggle-filled history - buildings, statues, and archaeological heritage such as rock art engravings or paintings, including sacred places like churches, mosques, temples, and graves. ${ }^{25}$ These tangible forms of cultural heritage are embedded in the rich history and bountifulness of South African culture and are worthy of preservation for that reason.

South Africa also has a diverse cultural and religious configuration, therefore making intangible heritage (symbolism) and living heritage (music, dance, narrative) essential parts of the nation's heritage resources. ${ }^{26}$ Intangible heritage refers to non-material heritage or culture, which includes traditions, languages, festivals, oral history, ceremonies, and indigenous knowledge systems. ${ }^{27}$ Intangible heritage such as indigenous knowledge systems (IKSs), referring to traditional and local knowledge that manifests in a range of areas including cultural and religious ceremonies, health interventions, and agricultural practices, also forms an important part of the nation's living heritage. ${ }^{28}$ It is worth noting that intangible heritage is by its nature not fixed to a permanent physical format, making it difficult to safeguard using the same legal and financial mechanisms established for tangible forms of heritage. This requires the integration of living heritage into the ambit of the management of tangible heritage resources. ${ }^{29}$ It is further submitted that intangible and tangible heritage need not have distinct and separate legal instruments safeguarding them, and that the existing dichotomies and inequalities must not be perpetuated. ${ }^{30}$

At the city level, heritage aspects cover issues such as urban planning or zoning, the provision of infrastructure and services, and the management of transportation. ${ }^{31}$ The importance of heritage can therefore not be underestimated, as it affects applications for land use and the approval of building plans, and needs to be coordinated with development planning, building control, law enforcement, and other functions. ${ }^{32}$ The aforementioned applies to cultural heritage resources in their broad sense.

25 DAC Experience the Vibrancy of South Africa's Cultural Diversity 20; s 2(ii)(b) of the NHRA; Manetsi State-Prioritised Heritage 26.

26 Deacon, Mngqolo and Prosalendis Protecting our Cultural Capital 1.

27 Deacon, Mngqolo and Prosalendis Protecting our Cultural Capital 1

$28 \quad$ National Heritage Council Critical Reflections on Heritage 21.

29 Manetsi 2006 South African Museums Association Bulletin 84.

30 Deacon et al Subtle Power of Intangible Heritage 6.

31 Srinivas $2020 \mathrm{https} / / / \mathrm{www} . g d r c .0 r g /$ heritage/heritage-strategies.html.

32

Davie 2019 http://www.theheritageportal.co.za/article/what-meaning-heritage. 


\section{The legal basis for the management of cultural heritage}

For local government to actively engage in CHRM, municipalities need to understand the relevant legally entrenched powers and functions in this regard. Through the interpretation of the law and policy provisions on CHRM, the section aims to establish what local government can contribute to the protection and management of cultural heritage.

\subsection{Constitutional provisions}

The Constitution establishes the framework for local cultural governance. Section 15 specifically addresses the right to freedom of conscience, religion, thought, belief and opinion. ${ }^{33}$ Adding that religious observances may be conducted at state or state-aided institutions, ${ }^{34}$ Rautenbach and Venter ${ }^{35}$ claim that while religion is ordinarily concerned with personal faith and belief, and culture relates to traditions and beliefs developed by a community, religious practices are frequently also informed by the customs and cultural beliefs of a community. In this vein section 15(2) allows state and state-aided institutions to make provisions for religious observances, meaning that they would have to designate specific spaces to these religious observances. ${ }^{36}$ Municipalities as organs of state have a corresponding duty to ensure that this right is realised and that communities have access to public spaces where they can conduct these observances, or at least ensure that state or state-aided institutions do not prohibit the conducting of these religious observances. ${ }^{37}$

Moreover, section 30 guarantees everyone the right to use the language and to participate in the cultural life of their choice. ${ }^{38}$ The wording of this section suggests that the Constitution promotes the language diversity of South Africa and simultaneously protects people's freedom to partake in their culture of choice subject to limitations. While this section does not define what constitutes "cultural life", one can argue that it refers to culture in broad terms. The protection of these rights is promoted in section 31, which grants the rights to persons to enjoy their culture, practice their religion and use their language in a communal setting. ${ }^{39}$ Based on these

Section 15(1) of the Constitution of the Republic of South Africa, 1996 (the Constitution).

Section 15(2) of the Constitution.

Rautenbach and Venter Rautenbach-Malherbe Constitutional Law 385.

Section 15(2)(a) of the Constitution.

Section 7(2) of the Constitution.

Section 30 of the Constitution.

Section 31(1)(a)-(b) of the Constitution. 
provisions it is not enough for municipalities merely to refrain from interfering in the exercise of a person's right to cultural life, but it is also their responsibility, as organs of state, to provide the space and freedom for the exercise of such a right. ${ }^{40}$

Additionally, the Constitution guarantees every person the right to an environment that is not harmful to their well-being and the right to have the environment protected through reasonable and other legislative measures. ${ }^{41}$ This "safe and healthy environment" also refers to an environment in which its cultural properties are protected. ${ }^{42}$ This view is expressed in the NEMA, which identifies aesthetic and cultural properties as constituents of the environment, with both characteristics being included in the description of cultural heritage..$^{43}$ Furthermore, well-being in this instance cannot be confined or restricted to direct impacts on a person. ${ }^{44}$ Well-being may also include notions of concern for the aesthetic and spiritual dimensions of the natural environment, including a sense of place (a concept commonly used in ascribing values to cultural heritage resources). ${ }^{45}$ In her exploration of the idea of a "sense of place" in the Karoo, Feris $^{46}$ highlights the important link between the biophysical and spatial environment and demonstrates how this relates to how people see themselves as connected through symbolic meanings related to culture and heritage, therefore proposing that a threat to a person's well-being, i.e. the person's sense of self, could also entail a threat to the person's culture or heritage.

Furthermore, Schedules $4 \mathrm{~B}$ and $5 \mathrm{~B}$ of the Constitution delineate the functional areas for which local government is responsible, which includes municipal planning, local amenities, and public places. It is arguable, based on reading sections $15,24,30$ and 31 of the Constitution with section $7(2)$, that when municipalities are required by law to integrate environmental concerns into their planning processes, those concerns should include cultural matters, despite the express provision of such powers or mandates and the express limitations of Schedules 4 and 5 of the Constitution. ${ }^{47}$ As

Section 7(2) of the Constitution.

Section 24 of the Constitution.

Based on s 24 of the Constitution and s 1(1)(xi)(iv) of the NEMA.

Section 1(1)(xi)(iv) of the NEMA; Rautenbach, Hart and Naudé "Heritage Resources Management" 824.

44 Du Plessis Fulfilment of South Africa's Constitutional Environmental Right 349.

45 See further Du Plessis 2015 PELJ 1855-1856; Feris "Making Legal Sense of a 'Sense of Place' in the Karoo" 395-408.

$46 \quad$ Feris "Making Legal Sense of a 'Sense of Place' in the Karoo" 395.

47 In terms of Schedule $4 A$ of the Constitution "cultural matters" is not an original function of local government but rather a function assigned to national and provincial 
Roodt states, it was never the true purpose of either Schedule 4 or Schedule 5 to draw boundaries around the powers of local government. ${ }^{48}$ Roodt adds that no constitutional provision denies local government the competency for cultural matters. ${ }^{49}$ Accordingly "there are very few indications that local authorities realise fully the importance that the principles of cooperative governance and inter-governmental relations as enunciated in Chapter 3 of the Constitution may have in interpretation and issues relating to effectiveness".$^{50}$ Hence, although it can be argued that cultural matters fall outside of the purview of local government when considering the constitutional allocation of functional matters in Schedules 4 and 5, these same schedules are not definitive delimitations of powers and functions. ${ }^{51}$ To this end CHRM is considered to be the responsibility of all three spheres of government.

\subsection{Heritage legislation pertaining to local government}

The NHRA introduces a three-tier system of management of heritage resources ${ }^{52}$ in which heritage resources of national significance are the responsibility of the SAHRA, ${ }^{53}$ provincial level functions the responsibility of PHRAs, and local level functions the responsibility of the local authorities (provided they have been declared as competent in terms of the NHRA). ${ }^{54}$ While the City of Cape Town and the HWC should be commended for their efforts in pushing for the devolution of powers to local authorities, the process has been plagued by several years of delays. ${ }^{55}$ Although these two authorities can serve as a template for the rest of the municipalities in South Africa, many challenges hinder the accreditation of heritage management. These challenges have been attributed to local government's concerns such as unequal access to basic municipal services, housing, infrastructure and

governments. However, s $7(2)$ of the Constitution provides that the state must "respect, protect, promote and fulfil all the rights in the Bill of Rights".

48

Roodt 2006 Fundamina 219.

Roodt 2006 Fundamina 219.

Roodt 2006 Fundamina 216.

Roodt 2006 Fundamina 217.

Section 8(1) of the NHRA. The criteria for heritage assessment and the system for grading include a) Grade I heritage resources are resources with qualities so exceptional that they are of special national significance, b) Grade II heritage resources, although forming part of the national estate, can be considered to have special qualities which make them significant within the context of a province, and (c) Grade III are other heritage resources worthy of conservation.

According to s 3(1) of the NHRA, the national estate consists of those resources that "are of cultural significance or other special value for the present community and for future generations". These constitute part of the country's national estate and should be managed by the relevant heritage resources authorities.

Section $8(6)$ (c) of the NHRA.

Smuts and Wiltshire "Heritage Management and the World Wide Web" 170. 
employment, inefficient land-use patterns, and unsustainable settlement trends. ${ }^{56}$ As Roodt ${ }^{57}$ points out, our society is heavily engaged in realising competing policy imperatives such as those of health, housing, and education. These competing imperatives seem at times to hinder the consideration of cultural heritage in development and planning. ${ }^{58}$ Beyond the challenges in municipalities specifically, it is argued that part of the challenges in the accreditation of local authorities by PHRAs may be attributed to the ineffective application of sections 8 and 23 of the NHRA by the SAHRA and PHRAs. ${ }^{59}$ Likewise, SAHRA's unsatisfactory performance in revising its minimum requirements for PHRAs and its inconsistency in reassessing the competence of the PHRAs, is linked to the complexity in devolution of $\mathrm{CHRM}^{60}$ Furthermore, the problems concerning the devolution of CHRM to the local level are also informed by some of the challenges faced by the provinces in relation to staff, skills, infrastructure, funding and governance. ${ }^{61}$

There are arguments that legislation at a national and provincial level, subject to some exceptions, does not sufficiently support the integration of heritage management into broader management processes. ${ }^{62} \mathrm{Ndlovu}$ believes that heritage legislation in South Africa has not proven to be an effective instrument in heritage management. ${ }^{63}$ The author contends that it is more common for the destruction of cultural heritage resources to occur without the consequence of legal proceedings being instituted. Few cases have been brought before the court and won. ${ }^{64}$ These arguments affirm that a greater degree of integration is necessary at a local level.

As a basic premise, the NHRA offers a set of principles that aims to influence and guide heritage authorities in the execution of their mandate to protect cultural heritage resources. ${ }^{65}$ This means that municipalities must adhere to the principles set out in terms of the NHRA when executing their functions. These principles proclaim that it is the responsibility of every

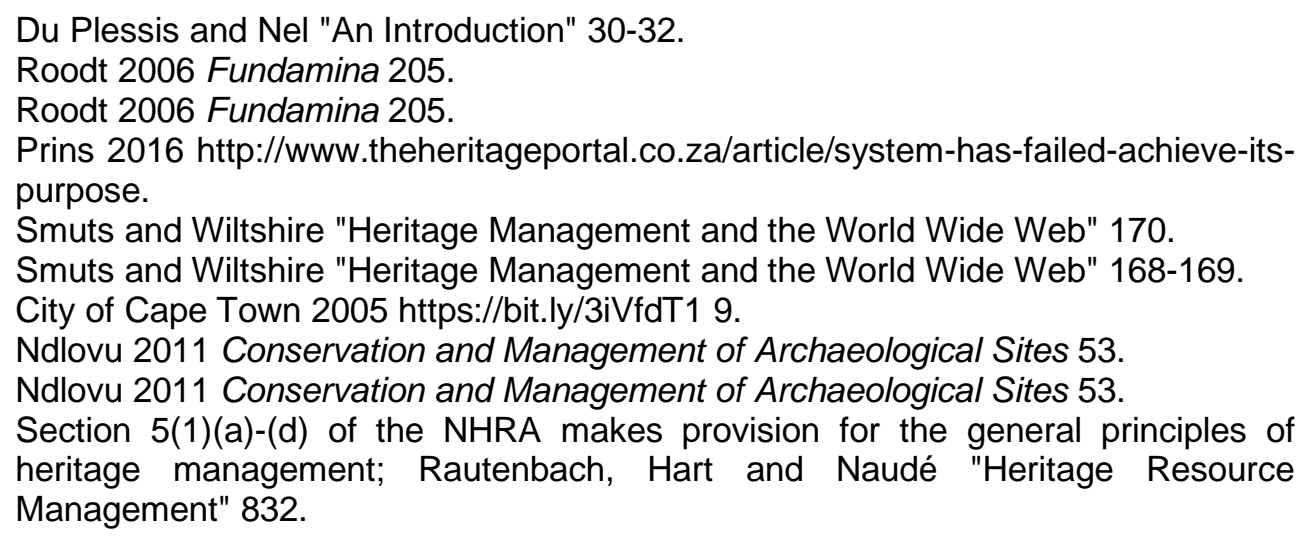


person to protect and manage national heritage (resources). ${ }^{66}$ This responsibility extends to both the local authorities (as legal personae) and the communities in their jurisdiction. ${ }^{67}$ It may be inferred that municipalities need to ensure the legal protection of cultural heritage resources by using their legally entrenched law-making powers in terms of the Constitution, the Local Government: Municipal Systems Act (the Systems Act), ${ }^{68}$ and the NHRA. The NHRA provides several tools for the management of heritage resources, including grading, surveys, heritage registers, and the designation of heritage areas. These provisions and tools are unpacked in separate paragraphs below, concerning local government specifically.

\subsubsection{Grading, heritage registers, and surveys}

The NHRA entrusts local government with the protection of Grade III cultural heritage resources, ${ }^{69}$ that is, heritage resources that have not received any grading yet and which are of local significance and value. ${ }^{70}$ While grading is an important step in the process towards the formal protection of a heritage resource, it does not provide formal protection but rather serves as a means of establishing an appropriate level of management to proceed with future formal protection. ${ }^{71}$

A municipality is assigned the duty of undertaking heritage surveys that identify and map heritage resources of potential significance in their jurisdictions. ${ }^{72}$ Rautenbach, Malherbe and Naudé ${ }^{73}$ contend that this tool aims to compile an inclusive atlas of sites to inform municipal decision-

66 Section 5(1)(b) of the NHRA provides that every generation has a moral responsibility to act as the trustee of the national heritage for succeeding generations.

Section 8(4) of the NHRA; s 2 of the Local Government: Municipal Systems Act 32 of 2000 (hereafter Systems Act). Local Government: Municipal Systems Act 32 of 2000.

69 Section 7(1)(a)-(c) and s 8(6)(a) of the NHRA. The competency of a PHRA or local authority shall be assessed in terms of criteria prescribed by the Minister.

70 Scheermeyer 2005 South African Archaeological Bulletin 121-123; Ndlovu 2011 Conservation and Management of Archaeological Sites 31-57. Heritage value is understood to refer to the importance people attach to a place for its ability to tell stories about the past that they want to preserve, share and pass on to future generations.

https://www.hwc.org.za/sites/default/files/2_3_6\%20Grading_Implications\%20and \%20Management_Approved.pdf 4.

72 Section 30(5) and (10) of the NHRA. A heritage survey is a survey of all heritage resources including but not limited to social significance, the built-form, spatial disposition and cultivated vegetation (including trees, avenues, gardens and even agricultural lands) that comprise the "built environment" and "cultural landscape" of a demarcated geographical area. 
makers and planners about potential areas of conflict in terms of zoning, ${ }^{74}$ but it may also serve to indicate where historically sensitive areas are located. In this way these surveys ensure that considerations of CHRM are factored into decision-making concerning development. This heritage survey results in an inventory or list of all the buildings, sites, and areas that are recommended to be designated as heritage resources, including recommendations for the grading of each of the latter. ${ }^{75}$

Likewise, municipalities are responsible for compiling and submitting an inventory of the heritage resources that fall in their areas of jurisdiction whenever they draft or revise their planning or zoning schemes, or spatial development frameworks (SDFs). ${ }^{76}$ This inventory needs to be in the form of an electronically spatially enabled database that is integrated into the development planning processes of the municipality. ${ }^{77}$ This inventory must then be submitted to the PHRA for consideration and for heritage resources worthy of conservation to be included on the heritage register. The mapped inventory ultimately informs the heritage register, heritage areas, and provincial and national inventories. ${ }^{78}$ Municipalities are also obliged to notify SAHRA and PHRAs when a place listed in the heritage register in its area of jurisdiction is destroyed. ${ }^{79}$

\subsubsection{Identification, protection and presentation of cultural heritage resources}

The NHRA requires municipalities to designate and manage heritage areas, which permits them to designate any area or piece of land to be a heritage area on the grounds of its environmental and cultural interest or due to the presence of heritage resources. ${ }^{80}$ As an additional form of protection,

$74 \quad$ Zoning refers to "the creation of areas, traditionally in cities or towns, within which certain use activities (residential, business, agricultural or industrial) are permitted or prohibited and where different restrictions with regard to buildings are applied (such as height, coverage of buildings and building lines)"- Van Wyk Planning Law 230. DEA Cultural Heritage Survey Guidelines 13. Section 30(5) of the NHRA. The local authority must, within six months of the PHRA publishing a notice in the Provincial Gazette for inclusion on the heritage register, make provision for the protection of heritage register sites through municipal by-laws or planning instruments.

Rautenbach, Hart and Naudé "Heritage Resource Management" 843.

DEA Cultural Heritage Survey Guidelines 26.

Section 30(10) of the NHRA.

Sections 31(5)(a) and (b) of the NHRA. However, this is subject to prior consultation with the PHRA, the owners of property in the area, and any affected community. 
municipalities are encouraged to integrate all designated heritage resources into their planning schemes or in by-laws to provide for their management. ${ }^{81}$

The NHRA further prohibits any person to subdivide or develop any part of a protected area unless the person consults with the heritage resources authority that designated the area per the prescribed procedure. ${ }^{82}$ This must take place at least 60 days before the changes are initiated. ${ }^{83}$ Should any alteration or development then be undertaken without the consent of the municipality, ${ }^{84}$ the municipality may order the owner to stop work and restore the site to its former condition. ${ }^{85}$ To avoid and remedy the potential risks and adverse effects that any development or project might have on cultural heritage, the NHRA prohibits any potential development or project from taking place without having obtained the proper authorisation for the execution of such an activity.

The fulfilment of this role may be facilitated by the making of by-laws regulating the admission to, controlling the conditions of use of, and protecting and managing protected areas. ${ }^{86}$

Municipalities are also responsible for coordinating and promoting the presentation and use of places of cultural significance and heritage resources that form part of the national estate and for which they are responsible. ${ }^{87}$ The presentation of these resources may be done for public enjoyment, education, research and tourism. ${ }^{88}$ This duty may be reconciled with the local government imperative to promote local economic development (LED)..$^{89}$ According to the White Paper on Local Government, 1998 municipalities can play a vital role in boosting local economies and job creation. ${ }^{90}$ Likewise, the history, diversity and cultural heritage of an area

Sections 28(6), 30(11) and 31(7) of the NHRA. This integration must be done through the consultation of and with the approval of a PHRA and a provincial planning authority.

Sections $27-29$ of the NHRA.

Section 27(21) of the NHRA.

Section 30(11)(a) requires the consent of a municipality for any alteration of or development to a place listed in the heritage register. Development consists of any physical intervention, excavation or action, other than that caused by natural forces, which may result in a change in the appearance or physical nature of a site in the core conservation area or influence its stability and future well-being.

Section 31(7)(c) of the NHRA.

Section 54 of the NHRA.

Section 44(1) of the NHRA.

Section 44(1) of the NHRA.

Section B, para 2.3 of the White Paper on Local Government, 1998 (GN 423 in GG

18739 of 13 March 1998) (White Paper on Local Government).

Section B, para 2.3 of the White Paper on Local Government. 
add to its unique qualities and should be sensitively accommodated in municipal development and planning so that such qualities may be retained as economic generators for tourism and business. ${ }^{91}$ This may be particularly useful considering that heritage tourism has been considered a feasible mode of development for local communities. ${ }^{92}$ By sustaining the attributes of heritage sites, communities may tap into the unexplored potential of cultural heritage for the development of tourism. ${ }^{93}$

Notably, municipalities have the duties of designating heritage areas, compiling and contributing to the heritage inventory in their designated areas, identifying and integrating these areas into their instruments such as by-laws and town-planning schemes, providing for the protection of their heritage resources through enforcing and implementing the chosen instruments, and fulfilling a reporting function with SAHRA and PHRAs. When one carefully considers and applies the provisions of the Constitution and the NHRA, the essential role municipalities can and should play in $\mathrm{CHRM}$ becomes rather pertinent.

\section{Local government instruments for CHRM}

As local level governors, municipalities are dependent on governance instrumentation to contribute to CHRM. The national legislative framework on the management of cultural heritage and local government provides a basket of local governance instrumentation that could potentially be used in CHRM efforts. These instruments are discussed in turn, below.

\subsection{By-laws for the protection of cultural heritage}

Local government has the authority to make and administer by-laws on matters in their functional areas, assigned or delegated to them, and incidental to the normal carrying out of their functions. ${ }^{94}$ The Systems Act affirms that municipalities are responsible for: a) implementing applicable national and provincial legislation and its by-laws, ${ }^{95}$ and b) passing by-laws inter alia on promoting a safe and healthy environment. ${ }^{96}$ These by-laws are

\footnotetext{
91 City of Cape Town 2005 https://bit.ly/3iVfdT1 3.

92 Gumede 2019 African Journal of Hospitality, Tourism and Leisure 2.

93 Gumede 2019 African Journal of Hospitality, Tourism and Leisure 2.

94 Sections 151(3), 156(1)(b), 156 (2) and 156(4) of the Constitution; Freedman 2014 $P E L J$ 578. It is the right and duty of the municipal council to govern the local government affairs of its local community as prescribed by $\mathrm{s} 4(1)$ (a) of the Systems Act.

95 Section 11(3)(e) of the Systems Act.

96

Section 11(3)(m) read with s 11(3)(I) of the Systems Act.
} 
passed by the Council of a municipality. ${ }^{97}$ This affords municipalities the ability to create by-laws concerning the identification, nomination, protection and management of cultural heritage resources. These instruments generally address only the tangible aspects, to the exclusion of the intangible values of heritage. Ndlovu points out that the NHRA, as heritage resources legislation, concerns itself merely with protecting and conserving sites that have a connection to living heritage, to provide access to those who may wish to perform various rituals. ${ }^{98}$ Likewise, the National Policy on Living Heritage, $2009^{99}$ encourages local governments to review their bylaws as well as develop by-laws that consider the challenges of cultural diversity.

The NHRA requires municipalities to provide for the protection of heritage (areas) through their zoning schemes or by-laws, hence municipalities may use these instruments to regulate access to, the use of, the protection of, the management of, incentives for, and fines for the despoliation of designated resources. ${ }^{100}$ As command and control instruments, by-laws provide a greater level of protection than any other governance instrument, due to their direct and immediate enforceability by the municipality. ${ }^{101}$ However, it is also argued that the capacity to make by-laws remains a challenge to South African municipalities, particularly as the drafting of "law" can be complex and onerous. ${ }^{102}$ These by-laws may therefore also be preceded or informed by municipal policies, strategies, plans or programmes on cultural heritage resources. ${ }^{103}$ Further means of protection of a heritage resource include the erection of signage indicating its status at or near the heritage area. ${ }^{104}$ Municipalities can also use financial mechanisms as part of their planning schemes or in their by-laws to assist with the conservation of heritage resources. ${ }^{105}$

Section 156(1) of the Systems Act empowers local government with the right to administer all the matters as listed in Schedules $4 \mathrm{~B}$ and $5 \mathrm{~B}$ and any other matter that has been assigned to it by national or provincial legislation.

Ndlovu 2011 Conservation and Management of Archaeological Sites 32. DAC National Policy on South African Living Heritage 45.

Section 31(7) read with s 54 of the NHRA.

$\mathrm{Nel}$, Du Plessis and Du Plessis "Instrumentation for Local Environmental Governance" 120-121.

$102 \mathrm{Nel}, \mathrm{Du}$ Plessis and Du Plessis "Instrumentation for Local Environmental Governance" 118.

103 Sections 11(3)(a) and (j) of the Systems Act. A municipality may monitor the impact and effectiveness of any of its services, policies, programmes and plans. Nel, Du Plessis and Du Plessis "Instrumentation for Local Environmental Governance" 121. 
Drafting by-laws on CHRM may also aid in providing certainty to developers concerning what the rules and principles are in terms of heritage management. This means that municipalities can pass specific by-laws relating to whether certain areas are appropriate for development. These by-laws could be more than just blanket provisions on CHRM. A municipality may prescribe specific restrictions in respect of such an area, especially where the proposed development is close to declared heritage resource areas. Municipalities have the licence to create innovative by-laws and may even elect to supplement these by-laws with other mechanisms such as incentives, policies, etc. ${ }^{106}$ Municipalities could equally put in place incentives as tools that ensure that heritage resources are enhanced, are maintained, and will contribute to local economic development. ${ }^{107}$ These incentives may be information-based, market-based or regulatory, and could contribute to the conservation of cultural heritage. Some of the incentives that could be put in place include tax incentives that allow owners of historic or artistic properties to avoid paying property taxes if they ensure that the property is kept in good condition, with its value and history intact. ${ }^{108}$ However, it is notable that financial incentives can be very expensive and can create an additional administrative burden for a municipality. ${ }^{109}$ Municipalities should therefore be cautious in their use of these tools.

\subsection{Planning instruments for cultural heritage protection}

Land management planning is the process of creating a blueprint for the future use of a given area. ${ }^{110}$ Its goal is to ensure that the various uses that are allocated for different purposes are managed in a way that is compatible with the character and welfare of both the area and its inhabitants. Land management planning takes place through integrated development plans (IDPs), SDFs and land use schemes (LUSs). ${ }^{111}$ The IDP is the execution of a municipality's duty to be development oriented and its municipal planning function as per the Constitution. ${ }^{112}$ The IDP is the principal, single most

106 Snijman and Petterson "Environmental Law Compliance and Enforcement" 294-295. Section 43(2) of the NHRA.

107 Rautenbach, Hart and Naudé "Heritage Resources Management" 849. Incentives may prove to be valuable tools considering that they reward good behaviour and penalise non-compliance. Nel, Du Plessis and Du Plessis "Instrumentation for Local Environmental Governance" 125.

108 Deacon et al Subtle Power of Intangible Heritage 54-55.

$109 \mathrm{Nel}$, Du Plessis and Du Plessis "Instrumentation for Local Environmental Governance" 126.

110 Van Wyk Planning Law 222.

111 Van Wyk Planning Law 222.

112 Sections 152(1)(c) and 153 of the Constitution. Schedule 4B of the Constitution and s 25(1) of the Systems Act. See ss 5(1)(a)-(c) of the Spatial Planning and Land Use 
inclusive, and most strategic planning instrument of municipalities and guides and informs all planning and development, and all decisions concerning planning, management, and development in the municipal area. ${ }^{113}$

The Systems Act obliges every municipality to include an SDF in its IDP, which is reiterated by the Spatial Planning and Land Use Management Act 16 of 2013 (the SPLUMA). ${ }^{114}$ The SDF is the principal strategic planning instrument that is used to decide if a change in land use rights (through the amendment of the LUS) should be allowed. ${ }^{115}$ Furthermore, municipalities need to develop and adopt a single LUS that gives effect to the municipal SDF and promotes economic growth, social inclusion, efficient land development, and minimal impact on public health, the environment and natural resources. ${ }^{116}$ The LUS must consist of regulations setting out the procedures and conditions relating to the use and development of land in any zone, a zoning map, and a register of all amendments to the LUS. An important mechanism to include in the LUS is zoning. Municipalities can identify and provide requirements for special zones to address municipal development priorities. ${ }^{117}$ Zoning aims to establish a framework, scheme, or plan in terms of which different uses are allocated to different areas. ${ }^{118}$ The creation of a Heritage Protection Overlay Zone (HPOZ) is a conceivable mechanism that municipalities could use to grant protection to a heritage area in their LUS. ${ }^{119}$

While both the SDF and LUS are required by law, the LUS has the force of law and can therefore be used to declare development illegal or can be used to enforce certain conditions or requirements on the development before it takes place. ${ }^{120}$ The LUS can provide for building recommendations in a given location and with regard to the heritage status of structures older than

Management Act 16 of 2013 (SPLUMA) for the definition of municipal planning. Also see Van der Berg Municipal Planning Law and Policy 158.

Section 35(1)(a) of the Systems Act; Van der Berg Municipal Planning Law and Policy 158.

114 Section 26(e) of the Systems Act. Ss 20(1) and (2) of the SPLUMA provides that each municipality must prepare and adopt, by notice in the Provincial Gazette, a municipal spatial development framework (SDF), which must form part of the municipality's Integrated Development Plan (IDP) in accordance with the provisions of the Systems Act. The SDF aims to provide guidance on the current spatial distribution and the desired use of land within a municipality. Section 21 of SPLUMA provides an outline of what a municipal SDF should contain. Section 25 of SPLUMA.

Section 24(3)(b) of SPLUMA.

Van Wyk Planning Law 231.

Section 31(7) of the NHRA.

Section 26(1)(a) of SPLUMA. 
65 years, for example. ${ }^{121}$ The LUS must also include policies that promote open space and develop public spaces for everyone. ${ }^{122}$ Municipalities can be as restrictive or flexible with their LUSs as required, according to their capacity to give effect to the scheme. These may include the use and development of land applications and the existing use of buildings and land. In addition to the national and the provincial decision-making criteria, the SPLUMA enables municipalities to pass by-laws to enforce their respective LUSs. ${ }^{123}$ Municipalities can also apply to a court for an order interdicting any person from using land in contravention of its LUS. ${ }^{124}$

The conservation of cultural heritage resources is possible only through cooperation by all levels of government in collaboration with local communities which can identify their heritage. ${ }^{125}$ The observance of the principle of subsidiarity is central to intra-governmental cooperation ${ }^{126}$ in the municipality as well as to inter-governmental cooperation between local government and the national and provincial spheres. ${ }^{127}$ The principle provides that provincial or national governments could assign a function under their competence to a municipality if that matter would most effectively be administered locally. ${ }^{128}$ This would mean that in some instances it may be best to address cultural matters on the level at which they are encountered, thus at the local government level. The Systems Act further compels municipalities to exercise their executive and legislative authority in the constitutional system of co-operative government envisaged in section 41 of the Constitution. ${ }^{129}$ This requires all three spheres of government to work in co-operation when it comes to cultural matters, for example. The role that this delineation of powers and functions plays is to effectively promote the management of cultural resources at different levels, which will in turn aid in streamlining development processes, amongst others. ${ }^{130}$

\footnotetext{
121 Section 24(2) of SPLUMA.

Sea Front for All v MEC Environmental and Development Planning Western Cape 20113 SA 55 (WCC) paras 42-43.

Section 32 of SPLUMA.

Section 32(2) of SPLUMA; Van Wyk Planning Law 511.

Barillet, Joffroy and Longuet Cultural Heritage and Local Government 15.

Du Plessis 2015 CILSA 294. The principle of subsidiarity is characterised by the decentralisation of responsibilities and resources to the lowest-appropriate level of government in order to achieve efficient and effective needs identification and service delivery.

Du Plessis 2015 CILSA 296.

Section 156(4) of the Constitution.

Section 3(1)(a) of the Systems Act.

Ndlovu 2011 Conservation and Management of Archaeological Sites 36.
} 


\section{CHRM instruments of the City of Cape Town Metropolitan Municipality}

This section looks at the measures taken by the City of Cape Town Metropolitan Municipality in the management and protection of cultural heritage resources under its jurisdiction. The objective is to illustrate how the City has managed to implement existing local government instruments for CHRM as provided for in law and to review the suitability of these instruments.

Cape Town has an exceptional cultural identity rooted in its geographical location, its people and history, which includes a wide range of resources such as historic buildings, townscapes and landscapes, graves, sacred spaces, memorials, and a large database of IKS, amongst others. ${ }^{131}$ The City is committed to ensuring that this diversity of cultural heritage is protected and promoted. ${ }^{132}$ The City affirms in its Arts, Culture and Creative Industries Policy (2014) that it has been running programmes or undertaking projects related to arts, culture, and the creative industries for many years, which programmes cross a wide range of departments, including those dealing with urban planning, social development, sports and recreation, parks and forests, library services, environment and heritage, tourism, economic development, and arts and culture, amongst others. ${ }^{133}$ The Policy was preceded by the Cultural Heritage Strategy (2005), a comprehensive plan that sets out the City's goals and targets for the management of the cultural heritage resources of Cape Town. ${ }^{134}$

For the sake of brevity, the discussion in this section looks at only the City's planning instruments and corresponding planning by-law. It is acknowledged, however, that local governance instruments such as the strategies and policies of the City may also constructively contribute to the City's CHRM efforts.

\footnotetext{
131 City of Cape Town 2005 https://bit.ly/3iVfdT1.

132 City of Cape Town 2017 http://www.capetown.gov.za/Local\%20and\%20 communities/Heritage-and-the-community/Heritage-resources/Heritageinformation-and-resources.

133 City of Cape Town 2014 https://bit.ly/3gPi3YB 11.

134 City of Cape Town 2005 https://bit.ly/3iVfdT1 3.
} 


\subsection{The City's IDP and SDF}

The City's IDP for the period 2017-2022 aims to build integrated communities through spatial transformation. ${ }^{135}$ It further seeks to promote and support cultural activities and to honour and respect events that enable communities to display their heritage by making optimal use of their existing facilities. ${ }^{136}$ This strategic aim is direct enforcement of the right to participate in cultural life as provided by the Constitution.

The City's first strategic focus area under its IDP is to position Cape Town as a globally competitive forward-looking city. ${ }^{137}$ Hence, the City has established the "intergovernmental legislation project", which aims to explore the introduction of a regulatory impact assessment. ${ }^{138}$ This impact assessment must therefore be aligned with the provisions of the NHRA and the NEMA. The City's "city heritage assets project" acknowledges the City's duty to maintain and manage the various heritage assets under its custodianship including both movable (artworks and objects) and immovable (buildings) heritage assets. ${ }^{139}$ The City has also launched a "citizen value programme" under which it established naming, heritage and anti-racism projects. ${ }^{140}$ The naming project is aimed at inclusivity through the naming and renaming of spaces, places and memorials which represent the heritage of all its residents. ${ }^{141}$ The heritage project seeks to protect the City's natural and cultural heritage by developing a heritage inventory $(\mathrm{HI})$. This $\mathrm{HI}$ will be compiled in consultation with HWC and will be a streamlined development application process. ${ }^{142}$ The City's heritage database currently has over 40000 entries of which more than half are Grade III heritage resources worthy of conservation. ${ }^{143}$ The heritage database includes Grade I and Grade II heritage sites managed by the SAHRA and the HWC respectively.

The City's municipal SDF (MSDF) is the framework that guides the municipality in its planning and the implementation of its IDP. ${ }^{144}$ The MSDF is aligned with the IDP, especially its first spatial priority, which is to build an

\footnotetext{
City of Cape Town Integrated Development Plan 2017-2022 53. City of Cape Town Integrated Development Plan 2017-2022 53. City of Cape Town Integrated Development Plan 2017-2022 57. City of Cape Town Integrated Development Plan 2017-2022 59. City of Cape Town Integrated Development Plan 2017-2022 68. City of Cape Town Integrated Development Plan 2017-2022 115-116.

City of Cape Town Integrated Development Plan 2017-2022 115. City of Cape Town Integrated Development Plan 2017-2022 115. City of Cape Town Smart Living Handbook 248.

City of Cape Town Integrated Development Plan 2017-2022 52.
} 
inclusive, integrated and vibrant city. ${ }^{145}$ In attempting to achieve this objective, the City commits to developing a comprehensive inventory of heritage resources in its municipal boundaries, which will include buildings, landscapes, and streetscapes. ${ }^{146}$ The City will also formulate and implement policies and procedures related to the management of heritage resources as well as administer and monitor the implementation of these policies and procedures. ${ }^{147}$ The provisions of these instruments indicate that heritage matters should be aligned with development and planning processes. ${ }^{148}$

\subsection{The City's Municipal Planning By-law}

The City has incorporated heritage management into its Municipal Planning By-law, 2015, which integrates cultural heritage into existing planning responsibilities. ${ }^{149}$ The City's By-law identifies the importance of heritage in section 99, which encompasses the criteria for the consideration of an application made in terms of the By-law. It follows that any development application must be considered, and might be refused or approved, based on the desirability of the proposed land use, amongst other considerations. ${ }^{150}$ The desirability of the proposed land use is determined in terms of factors such as the potential socio-economic impact, compatibility with the safety, health, and well-being of the surrounding community, the impact on heritage, and the impact on the biophysical environment. ${ }^{151}$ Through these provisions the City has full authority to refuse applications that may adversely affect the cultural heritage resources in its jurisdiction. This determination of desirability arguably promotes the consideration of heritage resources and may aid in protecting the cultural heritage resources in the jurisdiction of the municipality.

All properties in the City are subject to the integrated zoning scheme and land use provisions of the Development Management System. ${ }^{152}$ The Bylaw establishes inter alia the "Open Space Zoning" which applies to environmental conservation and public open spaces. ${ }^{153}$ Although properties zoned as open space are the most likely to be on the heritage register, this may also apply to properties with other zonings. The objective of such

\footnotetext{
145 City of Cape Town Integrated Development Plan 2017-2022 53.

146 City of Cape Town Municipal Spatial Development Framework 116.

147 City of Cape Town Municipal Spatial Development Framework 116.

148 Nawa Municipal Cultural Policy and Development in South Africa 12.

149 PN 204 in PG 7413 of 29 June 2015 (hereafter By-law) as amended.

150 Section 99(2)(d) of the By-law, substituted by $s$ 15(d) of the Amendment By-law of 2019 in PG 8185 of 6 December 2019.

151 Section 99(3)(f)-(i) of the By-law.

152 Schedule 3 of the By-law.

153 Parts 1 and 2 in Schedule 3 of the By-law.
} 
zoning is to create and regulate the use of infrastructure, facilities and recreational areas on public land, whilst aiming for the "conservation of cultural heritage resources" and the "protection of landscape and heritage areas". ${ }^{154}$ Regulation takes place by adopting a "primary and consent use" approach, meaning that certain developmental rules apply to the use of the property. ${ }^{155}$ The City may accordingly also require that a site development plan should be submitted by a developer for any of the various zonings. These provisions add to the argument offered earlier in this article ${ }^{156}$ that municipalities may set aside spaces where religious and cultural observances can be performed as a means of protecting intangible forms of heritage. These provisions in the By-law further speak to the mandate of municipalities as per sections 28(6), 30(11), 31(7) and 44(1) of the NHRA.

In the By-law, the City introduces additional local planning instruments such as heritage protection overlay zoning (HPO). ${ }^{157}$ The HPO provides a mechanism for the protection of heritage places the City considers to be conservation-worthy in terms of its heritage strategies. This tool is used to protect heritage places entered on the heritage register ${ }^{158}$ and for the protection of heritage areas as provided by the NHRA. ${ }^{159}$ The By-law expressly states that all established HPO zones are deemed to be heritage areas following the NHRA. ${ }^{160}$ The effect of this provision is that these declared areas are given automatic protection. The By-law offers a set of development rules, ${ }^{161}$ together with a few general provisions. ${ }^{162}$ The general provisions provide a list of activities that require the approval of the City if they affect a place or an area that is protected as an HPO zone. ${ }^{163}$ These listed activities are similar to the activities listed in section 38(1) of the NHRA and those provided in the NEMA Environmental Impact Assessment Guidelines. The approval of the City would be required, for example, for:

(b) any development, including any physical intervention, excavation, or action other than those caused by natural forces, which may in any way result in a

\footnotetext{
$154 \quad$ Parts 1 and 2 in Schedule 3 of the By-law.

155 Sections $97-103$ of Parts 1 and 2 of the By-law.

156 See the argument offered in section 3.2 above.

157 Sections 159-164 of the By-law.

158 Section 159(a) of the By-law makes provision for the application of HPO zonings on any heritage place that has been entered into the register of heritage resources maintained by the PHRA in accordance with the NHRA.

159 Section 159(b) of the By-law provides for the application of HPO zonings on any heritage area that has been designated in accordance with the NHRA.

160 Section 25 of the By-law.

161 Section 161(1)(a)-(b) and (2) of the By-law.

162 Section 162 of the By-law.

163 Section 162(1)(a)-(f) of the By-law.
} 
change to the appearance or physical nature of a heritage place, or influence its stability and future well-being .... ${ }^{164}$

In so-called heritage overlay zones the City has full decision-making powers for applications that do not affect a national or provincial heritage site. If implemented appropriately these measures can help to prevent developments (early in the process) that may infringe on the richness of the city's cultural heritage resources.

The By-law maintains that in deciding on a land use application the City must consider the effect of the proposed activity on the significance of the heritage area or place in question. ${ }^{165}$ The By-law further states that the City may, when approving the application, also impose any conditions appropriate for the protection of the heritage area or place. ${ }^{166}$ This could be a useful tool to protect the City's cultural heritage resources. The By-law also provides that the approval of the activity does not exempt the applicant from obtaining the approvals required by other laws such as the NEMA or NHRA, for example. ${ }^{167}$ The By-law is a concrete example of how a municipality can execute the law-making powers conferred on it by the provisions of the Constitution, national laws and framework legislation, to effectively manage and protect its cultural heritage resources.

\section{City of Cape Town and its cultural heritage in court}

This section reviews two cases involving the City of Cape Town and objections against proposed development projects. The pronouncement of the courts in these serves to judicially underscore the important role that local government can and should play in matters concerning the management of cultural heritage.

In Oudekraal Estates (Pty) Ltd $v$ City of Cape Town ${ }^{168}$ the development of a township in Cape Town was opposed due to the presence of burial sites (kramats) on the land, which was regarded as sacred. In this case, authorisation to develop the property had been granted in 1957, with engineering plans to proceed with development being submitted only in 1996. ${ }^{169}$ Following public outcry and an investigation into the validity of the approval of the township, the City contended that the approval had

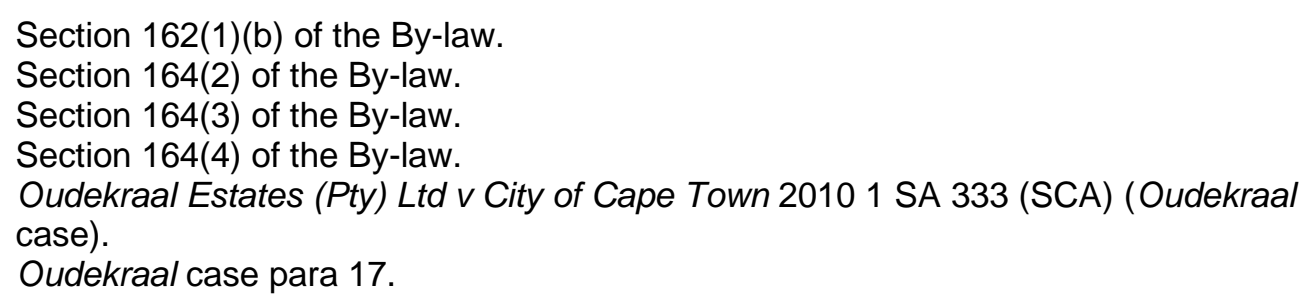


lapsed. ${ }^{170}$ The court granted the City's order to declare the approval to establish a township invalid and unlawful, stating that the entire area was regarded as sacred by a formerly marginalised section of South African society. ${ }^{171}$ The court held that having regard to the religious, cultural, and environmental rights of the community, the development could not commence, as these rights should be regarded as "integral to land development". ${ }^{172}$ Here, it is important to note that it was in the City's purview to comment on the application and to ensure that the community's objections against the development were duly considered.

In the last case the applicants in Bo-Kaap Civic and Ratepayers Association $v$ City of Cape Town ${ }^{173}$ approached the court to seek the review and setting aside of planning approvals granted in terms of the City of Cape Town's Municipal Planning By-Law, 2015. This dealt with the City's constitutional function of "municipal planning", which is inextricably connected to every functional area that concerns the use of land (i.e. tangible cultural heritage). ${ }^{174}$ The Bo-Kaap is an area situated on the slopes of Signal Hill above the city centre of Cape Town and is rich in history. In the Bo-Kaap case the applicants opposed the development of a section of a city block into a multi-storey, mixed-use building close to the Bo-Kaap, Riebeeck Square and Heritage Square. ${ }^{175}$ The applicants argued that the City had failed to engage appropriately with its PHRA, especially concerning failing to consider the complaints by the community in the Bo-Kaap area. ${ }^{176}$

On the City's heritage database, the Bo-Kaap is listed as a Provincial Heritage Site, a SAHRA Grade 1 Area and a proposed HPOZ. ${ }^{177}$ The substance of the appeal concerned whether the criteria under section 99 of the by-law were complied with by the City and the mayor as appeal authority. The essence of the matter was whether the decisions made by the City and the mayor were unreasonable and/or tainted by the erroneous

$170 \quad$ Oudekraal case paras 19, 20.

171 Oudekraal case paras 79, 116.

172 Oudekraal case paras 39, 75, 76.

173 Bo-Kaap Civic and Ratepayers Association v City of Cape Town 20184 All SA 93 (WCC) (hereafter the Bo-Kaap case) para 3. See section 5.2 for a discussion on the by-law related to this case.

174 Wary Holdings (Pty) Ltd v Stalwo (Pty) Ltd 20091 SA 337 (CC) paras 127-128; Van Wyk 2012 PELJ 289.

175 Bo-Kaap case para 2.

176 The HWC submitted that the development proposal in its current form was inappropriate given the heritage context and that it would have a detrimental effect on the heritage significance of both Riebeek Square and the Bo-Kaap. The Bo-Kaap case para 19. 
position taken by the City concerning heritage considerations. ${ }^{178}$ The appeal failed in this instance, as the court held that the City's officials and planning authorities thoroughly engaged with the heritage concerns of the objectors and with the developer. ${ }^{179}$ In this case the City had paid due regard to the planning policy imperatives and heritage legislation, yet the outcome of the case was unfavourable to the value and objectives of CHRM. It is notable that despite the judgement, the Bo-Kaap area was subsequently declared a national heritage site in terms of section 27 of the NHRA. ${ }^{180}$

The outcomes of these cases underscore that powers exist in each context. Municipalities are not necessarily given final decision-making powers but are often simply commentators on a decision made elsewhere. As seen in the case of Oudekraal, which was decided before any instrument on CHRM existed in the City, by merely considering the interests of their communities and conducting due diligence, municipalities can take on an important role in balancing heritage conservation against the need to develop, especially where many policy imperatives compete for attention. Secondly, in both cases it is evident that municipalities need to be vigilant in their roles as both the regulators and as the regulated, as the rights and duties applicable to them will have a significant impact on decisions taken locally. Beyond the drafting of local laws and policy, municipalities need to be capable of and willing to implement the national legislation they are charged with implementing. The outcome of these cases indicates that cultural interests must be considered and provided for in planning tools (local zoning schemes, for example). The consideration of cultural heritage resources must therefore inform decisions taken concerning development.

\section{Conclusion}

The objective of this article was to assess what local government can de jure contribute to CHRM and to explore the instruments the legal framework creates for municipalities to help give effect to CHRM. It was found that there is a definite, yet not always particularly clear, role for local government in CHRM. The authority to partake in CHRM is firstly derived from the interpretation of the rights in sections 15, 24, 30 and 31 read with section 7(2) of the Constitution. ${ }^{181}$ These rights place a duty on all organs of state, including municipalities, to ensure the protection of cultural and religious rights. Similarly, the NHRA assigns the following duties to municipalities: the

Bo-Kaap case para 65.

Bo-Kaap case paras 79, 81.

SAHRA 2020 https://www.sahra.org.za/notice-bo-kaap-declaration/.

See the discussion in section 3.1. 
identification of cultural heritage resources and the designation of land for their conservation; the recording thereof in a heritage register; the promotion, presentation and use of heritage resources; reporting to PHRAs; and empowering the making of by-laws regulating the admission to protected areas, controlling the conditions for the use of them, and protecting and managing them. ${ }^{182}$

Based on the above, local governments can develop comprehensive plans and procedures to identify, mitigate, and enhance the impacts of all development projects on their cultural heritage. ${ }^{183} \mathrm{It}$ is apparent that when making decisions and implementing plans, the protection and management of cultural heritage resources must be appropriately acknowledged. Furthermore, the City of Cape Town indicates through its planning instruments that protection is best afforded to cultural heritage resources through balancing the need to conserve heritage resources with the need for development. ${ }^{184}$ This is evidenced by the City of Cape Town's IDP and SDF, which set out the City's plans to manage and protect its heritage resources. Aside from the usual plans and regulations, cities can also explore the potential of local management plans, by-laws, or incentives. Due to their local binding force, by-laws are possibly the most authoritative regulatory instrument available for municipal administrations. ${ }^{185}$ By-laws bind both the municipality (its political and administrative structures) and the community (including residents, ratepayers, and non-governmental organisations). A by-law on CHRM may therefore aid in restricting activities that would have detrimental impacts on cultural heritage resources. In this way the local management of cultural heritage resources can aid in the streamlining the management of development applications at the municipal level. ${ }^{186}$ Regulatory tools and instruments such as by-laws and land-use schemes should accordingly be utilised to their full extent to provide the sufficient protection of cultural heritage resources and to avoid any further deterioration, loss and destruction of them.

The outcome in the Oudekraal and Bo-Kaap cases stresses the courts' acknowledgment of the importance of local authorities taking on the management of cultural heritage. ${ }^{187}$ Through the use of planning and

\footnotetext{
182 Sections 28(6), 31(1), (5), (7), and (8), 32, 44(1)(a)-(e), 47, and 54 of the NHRA. Also see section 3.2 of the discussion.

183 See section 3.2 and sections 5.1 and 5.2 of this article.

184 Section 5 of this article.

185 Section 1 of the Systems Act, Nel, Du Plessis and Du Plessis "Instrumentation for Local Environmental Governance" 94.

186 Rautenbach, Hart and Naudé "Heritage Resources Management" 846.

187 See the discussion in section 6 .
} 
strategic tools, local authorities can set out plans for promoting, protecting and managing heritage resources. The optimal use of the available governance instruments for CHRM, especially IDPs, SDFs and by-laws, will therefore be instrumental in achieving sustainable cultural governance. This would further enable a system of integrated CHRM on a local level.

\section{Bibliography}

\section{Literature}

Barillet, Joffroy and Longuet Cultural Heritage and Local Government Barillet C, Joffroy $\mathrm{T}$ and Longuet I (eds) Cultural Heritage and Local Government: A Guide for African Local Governments (Imprimerie Bastianeli Grenoble 2006)

Bredekamp 2006 International Journal of Intangible Heritage Bredekamp HCJ "Transforming Representations of Intangible Heritage at Iziko (National) Museums, South Africa" 2006 International Journal of Intangible Heritage 76-82

Butler and Ivanovic "Cultural Heritage Tourism Development"

Butler G and Ivanovic M "Cultural Heritage Tourism Development in PostApartheid South Africa: Critical Issues and Challenges" in Manwa $\mathrm{H}$, Moswete NN and Saarinen J (eds) Cultural Tourism in Southern Africa (Channel View Publications Bristol 2016) 58-75

City of Cape Town Integrated Development Plan 2017-2022

City of Cape Town Five-Year Integrated Development Plan 2017-2022 (City of Cape Town Metropolitan Municipality Cape Town 2017)

City of Cape Town Municipal Spatial Development Framework

City of Cape Town Municipal Spatial Development Framework 2017-2022 (City of Cape Town Metropolitan Municipality Cape Town 2018)

City of Cape Town Smart Living Handbook

City of Cape Town Smart Living Handbook: Making Sustainable Living a Reality in Cape Town Homes $5^{\text {th }}$ ed (City of Cape Town Metropolitan Municipality Cape Town 2020)

DAC Experience the Vibrancy of South Africa's Cultural Diversity

Department of Arts and Culture Experience the Vibrancy of South Africa's Cultural Diversity: Arts and Culture Guide 2010 (Department of Arts and Culture Pretoria 2010) 
DAC National Policy on South African Living Heritage

Department of Arts and Culture National Policy on South African Living Heritage (Department of Arts and Culture Pretoria 2009)

DAC Revised White Paper on Arts, Culture and Heritage Fourth Draft

Department of Arts and Culture Revised White Paper on Arts, Culture and Heritage Fourth Draft (Department of Arts and Culture Pretoria 2018)

DEA Cultural Heritage Survey Guidelines

Department of Environmental Affairs Cultural Heritage Survey Guidelines and Assessment Tools for Protected Areas in South Africa (Department of Environmental Affairs Pretoria 2016)

Deacon, Mngqolo and Prosalendis Protecting our Cultural Capital

Deacon H, Mngqolo S and Prosalendis S Protecting our Cultural Capital: A Research Plan for the Heritage Sector (HSRC Cape Town 2003)

Deacon et al Subtle Power of Intangible Heritage

Deacon $\mathrm{H}$ et al The Subtle Power of Intangible Heritage: Legal and Financial Instruments for Safeguarding Intangible Heritage (HSRC Cape Town 2004)

Du Plessis 2015 CILSA

Du Plessis AA "A Role for Local Government in Global Environmental Governance and Transnational Environmental Law from a Subsidiarity Perspective" 2015 CILSA 281-316

Du Plessis 2015 PELJ

Du Plessis AA "The 'Brown' Environmental Agenda and the Constitutional Duties of Local Government in South Africa: A Conceptual Introduction" 2015 PELJ 1846-1880

Du Plessis Fulfilment of South Africa's Constitutional Environmental Right Du Plessis AA Fulfilment of South Africa's Constitutional Environmental Right in the Local Government Sphere (LLD-thesis NWU 2008)

Du Plessis and Nel "An Introduction"

Du Plessis AA and Nel JG "An Introduction" in Du Plessis A (ed) Environmental Law and Local Government in South Africa (Juta Cape Town 2015) 3-40

Plessis and Rautenbach 2010 PELJ

Du Plessis AA and Rautenbach C "Legal Perspectives on the Role of Culture in Sustainable Development" 2010 PELJ 27-71 
Feris "Making Legal Sense of a 'Sense of Place' in the Karoo"

Feris L "Making Legal Sense of a 'Sense of Place' in the Karoo" in Glazewski $\mathrm{J}$ and Esterhuyse $\mathrm{S}$ (eds) Hydraulic Fracturing in the Karoo: Critical Legal and Environmental Perspectives (Juta Cape Town 2016) 395-408

Freedman 2014 PELJ

Freedman W "The Legislative Authority of the Local Sphere of Government to Conserve and Protect the Environment: A Critical Analysis of Le Sueur v eThekwini Municipality [2013] ZAKZPHC 6 (30 January 2013)" 2014 PELJ 567-594

Forrest International Law and the Protection of Cultural Heritage

Forrest C International Law and the Protection of Cultural Heritage (Routledge New York 2010)

Gumede 2019 African Journal of Hospitality, Tourism and Leisure

Gumede TK "Heritage Tourism as a Strategy for the Local Economic Development in KwaZulu-Natal, South Africa" 2019 African Journal of Hospitality, Tourism and Leisure 1-15

Jae Moon 2001 Administration and Society

Jae Moon M "Cultural Governance: A Comparative Study of Three Cultural Districts" 2001 Administration and Society 432-454

Keitumetse African Cultural Heritage Conservation and Management Keitumetse SO African Cultural Heritage Conservation and Management: Theory and Practice from Southern Africa (Springer Cham 2016)

Kotzé and Jansen van Rensburg 2003 Queensland U Tech L \& Just J Kotzé $L$ and Jansen van Rensburg $J$ "Legislative Protection of Cultural Heritage Resources: A South African Perspective" 2003 Queensland U Tech L \& Just J 1-20

Manetsi State-Prioritised Heritage

Manetsi T State-Prioritised Heritage: Governmentality, Heritage Management and the Prioritisation of Liberation Heritage in Post-Colonial South Africa (PhD-thesis University of Cape Town 2017)

Nawa Municipal Cultural Policy and Development in South Africa Nawa LL Municipal Cultural Policy and Development in South Africa: A Study of the City of Tshwane Metropolitan Municipality (LLD-thesis UNISA 2012) 
National Heritage Council Critical Reflections on Heritage

National Heritage Council of South Africa Critical Reflections on Heritage (National Heritage Council Durban 2012)

Ndlovu 2011 Conservation and Management of Archaeological Sites Ndlovu $\mathrm{N}$ "Legislation as an Instrument in South African Heritage Management: Is it Effective?" 2011 Conservation and Management of Archaeological Sites 31-57

Nel, Du Plessis and Du Plessis "Instrumentation for Local Environmental Governance"

Nel JG, Du Plessis W and Du Plessis AA "Instrumentation for Local Environmental Governance" in Du Plessis A (ed) Environmental Law and Local Government in South Africa (Juta Cape Town 2015) 91-166

Owosuyi 2015 PELJ

Owosuyi IL "The Pursuit of Sustainable Development through Cultural Law and Governance Frameworks: A South African Perspective" 2015 PELJ 2012-2059

Pereira Roders and Van Oers 2012 Journal of Cultural Heritage Management and Sustainable Development

Pereira Roders A and Van Oers R "Historic Cities as Model of Sustainability" 2012 Journal of Cultural Heritage Management and Sustainable Development 4-14

Phaswana-Mafuya and Haydam 2005 Museum Management and Curatorship

Phaswana-Mafuya $\mathrm{N}$ and Haydam N "Tourists' Expectations and Perceptions of the Robben Island Museum: A World Heritage Site" 2005 Museum Management and Curatorship 149-169

Rautenbach, Hart and Naudé "Heritage Resources Management" Rautenbach C, Hart D and Naudé M "Heritage Resources Management" in Du Plessis AA (ed) Environmental Law and Local Government in South Africa (Juta Cape Town 2015) 821-853

Rautenbach and Venter Rautenbach-Malherbe Constitutional Law Rautenbach IM and Venter R Rautenbach-Malherbe Constitutional Law $7^{\text {th }}$ ed (LexisNexis Johannesburg 2018) 
Roodt 2006 Fundamina

Roodt HC "Cultural Policy and the Landscape of the Law in South Africa" 2006 Fundamina 203-222

Scheermeyer 2005 South African Archaeological Bulletin

Scheermeyer C "A Changing and Challenging Landscape: Heritage Resources Management in South Africa" 2005 The South African Archaeological Bulletin 121-123

Smuts and Wiltshire "Heritage Management and the World Wide Web" Smuts $\mathrm{K}$ and Wiltshire $\mathrm{N}$ "Heritage Management and the World Wide Web: South African Challenges" in Sadr K, Esterhuysen A and Sievers C (eds) African Archaeology without Frontiers (Wits University Press Johannesburg 2014) 165-178

Snijman and Petterson "Environmental Law Compliance and Enforcement" Snijman $P$ and Petterson $T$ "Environmental Law Compliance and Enforcement" in Du Plessis AA (ed) Environmental Law and Local Government in South Africa (Juta Cape Town 2015) 291-318

UN-Habitat World Cities Report 2020

UN-Habitat World Cities Report 2020: The Value of Sustainable Urbanization (UN-Habitat Nairobi 2020)

Van der Berg Municipal Planning Law and Policy

Van der Berg A Municipal Planning Law and Policy for Sustainable Cities in South Africa (PhD-thesis Tilburg University and North-West University 2019)

Van Wyk 2012 PELJ

Van Wyk $J$ "Planning in All Its Guises: Which Spheres of Government Are Responsible?" 2012 PELJ 288-318

Van Wyk Planning Law

Van Wyk J Planning Law $3^{\text {rd }}$ ed (Juta Cape Town 2020)

Vollgraaff 2017 South African Museums Association Bulletin

Vollgraaff $\mathrm{H}$ "Museums and Cultural Landscapes: The ICOM-SA and ICOMOS-SA Initiative as a Case Study" 2017 South African Museums Association Bulletin 55-63 


\section{Case law}

Bo-Kaap Civic and Ratepayers Association v City of Cape Town 20184 All SA 93 (WCC)

Oudekraal Estates (Pty) Ltd v City of Cape Town 20101 SA 333 (SCA)

Sea Front for All v MEC Environmental and Development Planning Western Cape 20113 SA 55 (WCC)

Wary Holdings (Pty) Ltd v Stalwo (Pty) Ltd 20091 SA 337 (CC)

\section{Legislation}

Constitution of the Republic of South Africa, 1996

Local Government: Municipal Systems Act 32 of 2000

National Environmental Management Act 107 of 1998

National Heritage Resources Act 25 of 1999

Spatial Planning and Land Use Management Act 16 of 2013

\section{Government publications}

GN 423 in GG 18739 of 13 March 1998

PN 204 in PG 7413 of 29 June 2015

Proc in PG 8185 of 6 December 2019

\section{Internet sources}

City of Cape Town 2005 https://bit.ly/3iVfdT1

City of Cape Town 2005 IMEP Cultural Heritage Strategy https://bit.ly/3iVfdT1 accessed 15 June 2021

City of Cape Town 2014 https://bit.ly/3gPi3YB

City of Cape Town 2014 Arts, Culture and Creative Industries Policy https://bit.ly/3gPi3YB accessed 15 June 2021

City of Cape Town 2017 http://www.capetown.gov.za/Local\%20and\%20 communities/Heritage-and-the-community/Our-history-andheritage/Protecting-our-heritage 
City of Cape Town 2017 Protecting Our Heritage http://www.capetown.gov.za/Local\%20and\%20communities/Heritage-andthe-community/Our-history-and-heritage/Protecting-our-heritage accessed 3 January 2020

City of Cape Town 2017 http://www.capetown.gov.za/Local\%20and\%20 communities/Heritage-and-the-community/Heritage-resources/Heritageinformation-and-resources

City of Cape Town 2017 Heritage Information and Resources http://www.capetown.gov.za/Local\%20and\%20communities/Heritage-andthe-community/Heritage-resources/Heritage-information-and-resources accessed 3 January 2020

Davie 2019 http://www.theheritageportal.co.za/article/what-meaningheritage

Davie L 2019 What is the Meaning of Heritage? http://www.theheritageportal.co.za/article/what-meaning-heritage accessed 15 April 2020

HWC 2016 https://www.hwc.org.za/sites/default/files/2_3_6\%20Grading_ Implications\%20and\%20Management_Approved.pdf

Heritage Western Cape 2016 Clarification of Grade III Heritage Resources https://www.hwc.org.za/sites/default/files/2_3_6\%20Grading_Implications \%20and\%20Management_Approved.pdf accessed 15 June 2021

Prins 2016 http://www.theheritageportal.co.za/article/system-has-failedachieve-its-purpose

Prins H 2016 The System Has Failed to Achieve Its Purpose http://www.theheritageportal.co.za/article/system-has-failed-achieve-itspurpose accessed 15 June 2021

SAHRA 2020 https://www.sahra.org.za/heritage-protection/

South African Heritage Resources Agency 2020 Heritage Protection https://www.sahra.org.za/heritage-protection/ accessed 3 January 2020

SAHRA 2020 https://www.sahra.org.za/notice-bo-kaap-declaration/ South African Heritage Resources Agency 2020 Notice Bo-Kaap Declaration https://www.sahra.org.za/notice-bo-kaap-declaration/ accessed 3 January 2020 


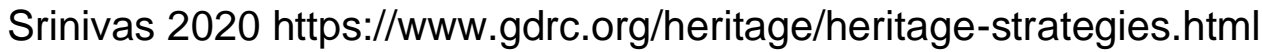
Srinivas H 2020 Heritage and Conservation Strategies: Understanding the Justifications and Implications https://www.gdrc.org/heritage/heritagestrategies.html accessed 15 June 2021

\section{List of Abbreviations}

CHRM

CILSA

DAC

DEA

$\mathrm{HI}$

$\mathrm{HPO}$

$\mathrm{HPOZ}$

HWC

IDP

IKS

LED

LUS

MSDF

NEMA

PELJ

NHRA

PHRA

Queensland $U$ Tech $L$ \& Just $\mathrm{J}$

SAHRA

SDF

SPLUMA
Cultural heritage resources management

Comparative and International Law Journal of Southern Africa

Department of Arts and Culture

Department of Environmental Affairs

Heritage inventory

Heritage protection overlay

Heritage Protection Overlay Zone

Heritage Western Cape

Integrated development plan

Indigenous knowledge system

Local economic development

Land use schemes

Municipal spatial development framework

National Environmental Management Act 107 of 1998

Potchefstroom Electronic Law Journal

National Heritage Resources Act 25 of 1999

Provincial Heritage Resources Authority

Queensland University of Technology Law and Justice Journal

South African Heritage Resources Agency

Spatial development framework

Spatial Land Use and Management Act 16 of 2013

United Nations 